\section{BEHAVIOUR OF METAL GRAINS}

Recrystallization, Grain Growth and Textures (Papers presented at a Seminar of the American Society for Metals, Oct. 16-17, 1965.) Pp. xvi+617. (Metals Park, Ohio: American Society for Metals, 1966. Distributed in the United Kingdom by Chapman and Hall, Ltd.) $192 s$.

ELEVEN papers were presented at this seminar covering cold work, recovery, recrystallization, grain growth and textures in metals, together with one on the crystallization of amorphous alloys and one on crystal morphology and textures in polymers. At the seminar the papers were arranged in related order to cover well defined areas, but in the interests of rapid publication, the original order has not been followed in the book; this is a pity. Nevertheless, to find in one volume so many excellent review papers, together with discussion contributions of varying lengths, largely makes up for this small disorder.

To mention names, the nature of the cold-work state is considered by the Basinskis and recovery processes in metals by Li. Deformation textures of metals are considered by $\mathrm{Hu}$, Cline and Goodman with discussion from four sets of authors. The nature of grain boundaries is reviewed by Shewmon and grain coalescence, grain boundary migration, and the applications of quantitative metallography to recrystallization studies are treated by Nielsen, Gordon, and Vandermeer and Hilliard respectively. Contributions on recrystallization mechanisms come from Cahn, Burgers, Detert and Speich and Fisher; Beck and $\mathrm{Hu}$ review the oriented-nucleation versus oriented-growth mechanisms for the origin of recrystallization textures, and several authors including Lücke contributed to the discussion of this section. Dunn and Walter have written a lengthy review of secondary recrystallization and Mader deals with the crystallization of amorphous alloys prepared by rapid quenching, or by co-evaporation of the components of the alloy. Finally, Holland has presented an interesting review drawing attention to the similarities between metals and polymers both in their crystalline morphology and in their mechanical properties.

It is a pleasure to commend this book to both metallurgists and to materials scientists, and there is no doubt that this will become the standard reference work in this field for a number of years to come. The book is well produced with the high quality of illustration that we have come to expect from the American Society for Metals, and both this and the continuing high standard of the seminars set an object lesson for societies in other countries.

P. L. Pratt

\section{ARTIST'S LIFE}

\section{John James Audubon}

A Biography. By Alexander B. Adams. Pp. $510+21$ photographs. (London: Victor Gollancz, Ltd., 1967.) 528. $6 d$. net.

No one could have predicted, before he reached his midthirties, that J. J. Audubon would become America's most famous bird artist. He was hopelessly spoiled as a child, and in his twenties and early thirties lost all his own money, and much of other people's, in one impractical business scheme after another. Further, he quarrelled with almost everyone, especially those who helped him. From about the age of thirty-five, when he started to earn a meagre and uncertain living from drawing portraits, he collected and sketched birds more seriously, but it was only when he came to Britain at the age of 41 that he became famous. It was then that he began to produce the great volumes that made his name, and it was after his return to the United States that he made his best collecting trips, to Florida, Nova Scotia and the prairies. This book gives a straightforward account of Audubon's life, but it is far too long, especially because there is no appraisal of Audubon's artistic output, or of the way in which he drew and painted, or of wild nature as it then existed in the United States. Further, the social milieu of the places in which Audubon lived could have been enlarged upon.

D. LACK

\section{OBITUARIES}

\section{Dr C. R. Ribbands}

Charles Ronald Rrbbands died in a road accident on March 30, 1967, at the age of 53. His contribution to entomology covered a wide range of topics including research on insecticides, ecology and behaviour.

$\mathrm{He}$ entered Downing College, Cambridge, as an exhibitioner in 1932 and graduated in 1935. His early career included brief periods of research in the Department of Zoology at the University of Glasgow and at the John Innes Horticultural Institute, and teaching at University College School, Hampstead. In 1938 he returned to Glasgow as an assistant in the Department of Zoology, to study meiosis in plant and animal material.

In 1940 he voluntarily enlisted in the Royal Army Medical Corps and served with a Field Hygiene Section and Malaria Field Laboratory in Sierra Leone and West Africa, where he established a reputation in malariology and the ecology and control of anopheline mosquitoes. There he worked on the attractiveness of human populations to mosquitoes and on fluctuations in the size of mosquito populations. He was a pioneer in the uses of DDT and gammexane as mosquito larvicides. In 1943 he was posted to South East Asia and India as officer commanding No. 2 Entomological Field Unit, to plan and conduct research on new insecticides and methods of controlling malaria and scrub typhus.

Ribbands is best known for his post-war research on honey-bees which he began at Rothamsted Experimental Station in 1947. His approach to bee research was typically vigorous and he revitalized the study of the social life of honey-bees, doing much to develop the subject at a time when the recent discovery of dance language in bees made a new approach imperative. His series of experiments and observations on division of labour, foraging, and orientation behaviour corrected many of the misconceptions that had accumulated and emphasized the flexibility of the behaviour of individual bees. $\mathrm{He}$ rightly regarded his discovery of the extensiveness of food transmission between members of a honey-bee colony as his most important finding. This discovery greatly helped subsequent research and its importance in the organization of the honey-bee colony is the central theme of his book, The Behaviour and Social Life of Honeybees, which quickly became an obligatory text-book for any student of bee behaviour.

In 1955 he was awarded an ScD (Cantab.) for his contributions to entomologyand in 1956 returned to Cambridge as lecturer in agricultural entomology, the post he held until his death. As well as teaching in the School of Agriculture and the Department of Zoology, he transferred his attention to the control of sources of virus yellows in sugar beet and to the role of aphids, especially apterae, in the spread of viruses within erops.

During 1951 he was elected to the council of the Association for the Study of Animal Behaviour, and he became its honorary treasurer in 1953. Latterly he was also active in university affairs and was a founder member and fellow of University College, Cambridge. To all these posts, as to his research, Ribbands brought a characteristic intensity of purpose and a determination to succeed, which was typical of his attitude to work and to living.

Trevor Lewts 